\title{
Atlantoaxial Instability in a Patient With Down's Syndrome
}

\section{Down Sendromun Eşlik Ettiği Atlantoaksiyel Instabilite Olgusu}

\author{
Şeyma Yıldız, Nuri Havan, Hüseyin Toprak, İssam Cheik Ahmad
}

Bezmialem Vakıf Universitesi, Radyoloji Anabilim Dalı, İstanbul

Yazışma Adresi / Corresponding to:

Uzm. Dr. Şeyma Yildiz, Bezmialem Üniversitesi, Fatih Istanbul - Türkiye

Tel: 05326775887, Mail: drseymayildiz@gmail.com

Down sendromu insidansı yeni doğanda 1: 750-1000 olup, en sık görülen kromozom bozukluğudur. Asemptomatik atlantoaksiyel instabilite prevalansı oldukça yaygındır ancak semptomatik atlantoaksiyel instabilite oranı nadirdir. Bu yazıda, Down sendromlu atlantoaksiyel instabilite olgusunun ameliyat sonrası görüntüleri tartışılmıştır.

Anahtar Kelimeler: Down sendromu, atlantoaksiyel instabilite; magnetic rezonans inceleme

Incidence of Down syndrome, the most common chromosomal disorder defined in literature, is 1: 750-1000 in the newborn population. The prevalence of asymptomatic atlantoaxial instability is relatively common but the incidence of symptomatic atlantoaxial instability is rare. We present this case with interesting postoperative images of the atlantoaxial instability in a patient with Down syndrome.

Keywords: Down syndrome, atlantoaxial instability; magnetic resonance imaging 


\section{Introduction}

Down syndrome (trisomy 21) was identified by John Langdon Down in 1866. Incidence of Down syndrome is 1:750-1000 in new born. It is the most common chromosomal disorder. Findings such as cranio-facial dimorphism, mild to moderate mental retardation, congenital heart defects, hypotonic, gastrointestinal problems, immune deficiency, atlanto-axial instability can be existed ${ }^{1}$.

The prevalence of asymptomatic atlanto-occipital instability is relatively common in individual with Down syndrome, exists in 10 to $20 \%$ of the cases ${ }^{2-4}$. The rate of symptomatic atlanto-occipital instability is approximately $1-2 \%$. Our aim in this report was to report atlanto-axial instability in a patient with Down syndrome and with instability symptoms.

\section{Case report:}

14-year-old patient with Down syndrome was admitted to paediatric neurology clinic with complaints of difficulty in walking for 2 months and neck pain. The patient had no story of trauma and another speciality. Cranial magnetic resonance imaging (MRI) was performed to rule out an intracranial pathology. On MRI, the the distance between the odontoid and clivus basion was measured $18 \mathrm{~mm}$ and atlanto-dental distance was measured $16 \mathrm{~mm}$; these findings were consitent with atlanto-occipital dislocation, and atlanto-axial instability (Fig. $1 \mathrm{a}, \mathrm{b})$. Findings consistent with spinal cord compression were present and signal changes consistent with myelomalacia were seen on T2-w images. Multislice computed tomography (MDCT) was performed to evaluate craniocervical junction bony pathologies. On CT examination, foramen magnum was found to be significantly narrow (the width of the foramen magnum was $4 \mathrm{~mm}$ )

In examination foramen magnum has been observed significantly narrow (channel width $4 \mathrm{~mm}$ ) (Fig. 2a, 2b). Accompanying bony abnormalities were not present. Instability was successfully corrected by C1-C2 fusion in the operation. On postoperative CT scan, the width of foramen was normal (13 $\mathrm{mm})$. At C1 and C2 levels, metallic surgical materials passing through the laminae were seen and the distance between the dens and axis was large. On postoperative MRI, findings consistent with spinal cord compression dissappeared but sig- nal changes consistent with myelomalacia were going on T2weighted images.
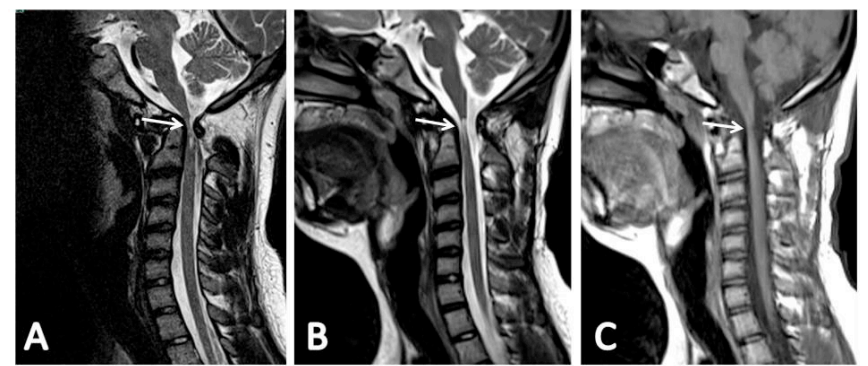

Figure 1; Increased atlanto-dental distance, prominent narrowing of spinal canal and slimming and myelomalaciac changes of cord (white arrow) on sagittal T2-weighted MR images (A), Normal atlanto-dental distance after operation on sagittal T1 and T2-weighted MR images, myelomalaciac changes of cord (white arrow) after surgery persisted on sagittal T2-weighted MR images (B)
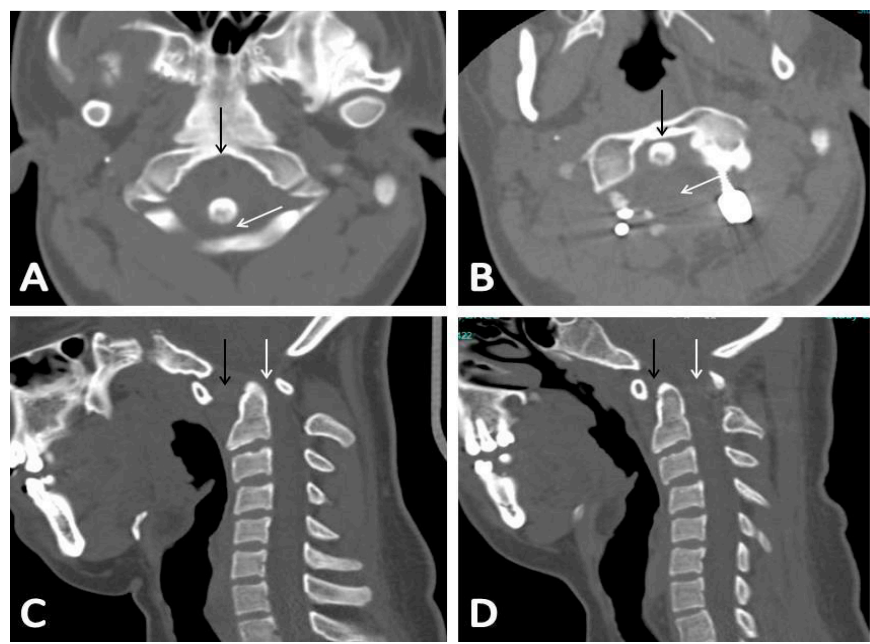

Figure 2; Atlanto-axial instability and atlanto-occipital dislocation (black arrow), narrowing of spinal canal and slimming of cord (white arrow) on preoperative axial and sagittal CT images (A, C), Normal atlanto-dental distance (black arrow) and neural canal width (white arrow) after surgery on axial and sagittal CT images (B, D)

\section{Discussion:}

Atlanto-axial insitability is depended on extremely mobile joint (because of various reasons) between atlas and axis. Instability generally depends on trauma. Down Syndrome is among the non-traumatic causes of instability. Laxity of ligament or cervical vertebra bone growth abnormalities are usually responsible for instability developed in Down syndrome ${ }^{3-5,6}$. It has been thought that generalized ligamentous laxity is due to intrinsic defect at collagen metabolism. Bone anomalies at 
atlanto-axial or atlanto-occipital junction are among the reasons for instability ${ }^{7}$.

Atlanto-occipital instability at Down's syndrome is a known condition ${ }^{7}$. Although 10-20 \% of the patients are affected, it rarely becomes symptomatic or has positive neurological examination findings ${ }^{3-5}$. While our Down syndrome diagnosed case was asymptomatic up to adolescent period, 14 years old patient was admitted to hospital with complaints of sudden walking difficulty.

Atlanto-axial distance is the distance from the surface posterior surface of anterior arch of C -1 to anterior surface of dens, above $3 \mathrm{~mm}$ is accepted pathological. In our case it was measured as $16 \mathrm{~mm}$. The neural canal width is defined as the distance from the posterior surface of the dens to anterior surface of the posterior arch of C-1, while above $13 \mathrm{~mm}$ was accepted normal, in our case it was $4 \mathrm{~mm}$. The neural canal width is indicative for spinal cord injury ${ }^{7-9}$. Instability is diagnosed if measurement of anterior atlanto-odontoid distance in lateral cervical radiograph which is taken at positions of flexion-extension is above $4 \mathrm{~mm}$ under the age of 15 and 3 $\mathrm{mm}$ over the age of $15^{4}$.
In cases with a diagnosis of atlanto-axial instability, MRI can be used to evaluate spinal cord. Signal changes associated with spinal cord compression or trauma can be evaluated ${ }^{8}$. In our case, spinal cord compression was present and hyperintense signal changes consistent with myelomalacia was seen in the spinal cord on T2-weighted images.

In cases with Down's syndrome who want to exercise are recommended to be screened for asymptomatic cervical instability. If the distance between odontoid and anterior arch of C1 is above $4.5 \mathrm{~mm}$ or in the presence of abnormal odontoid, to protect the person from potential head and neck injury the person should not be accepted to participate in sport activities $^{5}$. The screening before surgery is recommended for the patients with Down syndrome who will undergo an operation to prevent from secondary complications of positions taken during anaesthesia and manipulations ${ }^{10}$.

As a result, non-traumatic atlanto-axial insitability is a rare but vital pathology in cases with Down syndrome. In symptomatic patients with Down sydrome or when new motor deficits develop, CT and/or MRI should be performed to evaluate craniocervical pathology.

\section{References}

1. Maina PK, Milind S.T, Mamta N. Down Syndrome: Clinical profile from India. Arch Med Res 2004;35:31-35.4.

2. Atlantoaxial instability in Down syndrome: subject review. American Academy of Pediatrics Committee on Sports Medicine and Fitness. Pediatrics 1995;96:151-154.

3. Semine AA, Ertel AN, Goldberg MJ, Bull MJ. Cervical spine instability in children with Down syndrome (Trisomy 2i). J Bone Joint Surg (AM) 1978;60:649-652

4. Pueschel SM, Scola FH, Perry CD, Pezzullo JC. Atlanto-axial instability in children with Down syndrome. Pediatr Radiol 1981:10:129-132

5. Schaffer TE, Dyment PG, Luckstead EF, Murray JJ, Smith NJ. Committee on sports medicine: atlanto-axial instability in Down syndrome. Pediatrics 1984;74: 152-154

6. Martel W. The occipito-atlanto-axialjoints in rheumatoid arthritis and ankylosing spondylysis. AJR 1961;86:223-240

7. Spitzer R, Rabinowitch JY, Wybar KC. A study of the abnormalities of the skull, teeth and lenses in mongolism. Can Med Assos J 1961;84:567-672.

8. Brockmeyer D. Down Syndrome and Craniovertebral Instability. Pediatr Neurosurg 1999;31:71-77

9. Tishler J, Martel W. Dislocation of the atlas in mongolism. Radiology 1965;84:904-906

10. Harley EH, Collins MD. Neurologic sequelae secondary to atlantoaxial instability in Down syndrome. Implications in otolaryngologic surgery. Arch Otolaryngol Head Neck Surg 1994;120:159-65 